\title{
Pengaruh Pengolahan Terhadap Nilai Fungsional Bawang Putih (Allium sativum)
}

\author{
Chessa Uly Thalia ${ }^{1 *}$, Ruth Chrisnasari ${ }^{1}$, Ardhia Dheasy Rosita Dewi ${ }^{1}$ \\ ${ }^{1}$ Fakultas Teknobiologi, Universitas Surabaya, Raya Kalirungkut Surabaya-Indonesia 60293 \\ *corresponding author: chessauly@gmail.com
}

Abstract - Organosulphur compounds in garlic has bactericidal effect and antioxidant potentials. However, toxic effects and strong odor produced by the compound allicin contribute to the reduction of garlic consumption. The production of allicin compound can be inhibited by skipping grinding and substituting it with other methods such as heating with oven and soaking in salt water, so the production pathway of organosulphur compounds will produce S-allyl cysteine which have lower toxic effect and antioxidant activity up to six fold compared to allicin. This research is done as a preliminary test to know the effect of process towards functional value of garlic. The results showed that the best treatment for black garlic $\left(80^{\circ} \mathrm{C}\right.$ for 40 days) and pickled garlic (salt concentration of $3 \%$ for 40 days) has antioxidant activity $(37,03 \%, 72,30 \%$, and $32,17 \%)$, phenolic content $(0,50 \mathrm{mg}$ GAE/g sample, 1,09mg GAE/g sample, and $0,146 \mathrm{mg} \mathrm{GAE} / \mathrm{g}$ sample), vitamin $\mathrm{C}$ content $(0,068 \% \mathrm{~b} / \mathrm{b}, 0,348 \% \mathrm{~b} / \mathrm{b}$, and $0,054 \% \mathrm{~b} / \mathrm{b})$, and protein content $(3,1 \% \mathrm{~N}, 7,61 \% \mathrm{~N}$, and $1,45 \% \mathrm{~N})$ respectively that was significantly different (pvalue $<0,05)$, antimicrobial activity and total plate count test was not significantly different (pvalue $>0,05$ ). Therefore, the process that gives the highest functional value was the black garlic.

Keywords: garlic, black garlic, pickled garlic, functional food, antioxidant activity, phenols, alliin, S-allyl cysteine

\begin{abstract}
Abstrak - Senyawa organosulfur dalam bawang putih memiliki efek bakteriosidal dan potensi sebagai antioksidan. Namun, adanya efek toksik dan bau menyengat yang dihasilkan oleh senyawa allisin mengurangi daya konsumsi masyarakat. Produksi senyawa allisin dapat dihambat dengan menghilangkan penggerusan dan melakukan pengolahan yang lain, yaitu pengovenan dan perendaman pada air garam, sehingga jalur produksi senyawa organosulfur akan menghasilkan S-allyl cysteine dengan efek toksik jauh lebih kecil namun aktivitas antioksidan enam kali lebih tinggi dibandingkan allisin. Penelitian ini sebagai uji pendahuluan untuk mengetahui pengaruh pengolahan terhadap nilai fungsional bawang putih. Dari hasil uji, bawang putih, perlakuan terbaik bawang hitam (suhu $80^{\circ} \mathrm{C}$ selama 40 hari), dan pickled garlic (kadar garam $3 \%$ selama 40 hari) secara berturut-turut memiliki aktivitas antioksidan (37,03\%, 72,30\%, dan 32,17\%), senyawa fenolik total (0,50mg GAE/g sampel, 1,09mg GAE/g sampel, dan 0,146mg GAE/g sampel), kadar vitamin C (0,068\% b/b, 0,348\% b/b, dan 0,054\% b/b), dan kadar protein $(3,1 \% \mathrm{~N}, 7,61 \% \mathrm{~N}$, dan $1,45 \% \mathrm{~N})$ yang berbeda signifikan (pvalue $<0,05)$, aktivitas antimikroba dan uji total plate count tidak berbeda signifikan ( $p$ value $>0,05$ ), sehingga pengolahan yang memberikan nilai fungsional tertinggi yaitu bawang hitam.
\end{abstract}

Kata kunci: bawang putih, bawang hitam, pickled garlic, pangan fungsional, aktivitas antioksidan, fenolik, alliin, S-allyl cysteine.

\section{PENDAHULUAN}

Bawang putih merupakan salah satu bahan makanan yang sudah umum digunakan oleh masyarakat, baik untuk bahan masakan, pemberi aroma, maupun tindakan pencegahan dan penyembuhan berbagai penyakit (Amagase et al, 2006). Umbi bawang putih dikenal memiliki efek bakteriostatis dan bakteriosidal karena kandungan zat aktif alliin-nya (Untari, 2010), memiliki potensi aktivitas antioksidan (Borek, 2001), kemampuan untuk menstimulasi respon imunologi, dan modulasi dari sintesis prostanoid (Chang, 2005). Banyaknya manfaat bawang putih dapat difungsikan oleh masyarakat sebagai suplemen untuk kesehatan. Namun, karena bawang putih memiliki toksisitas yang tinggi dan bau yang menyengat ketika dimakan tanpa diolah, perlu adanya pengolahan bawang putih untuk dapat dijadikan suplemen dan dikonsumsi oleh masyarakat.

Pengolahan bawang putih biasa dilakukan masyarakat seperti penggerusan akan mengaktivasi enzim alliinase dan merubah senyawa alliin menjadi komponen allisin yang 
menimbulkan bau menyengat. Allisin dikenal memiliki kemampuan membunuh bakteri dan mencegah infeksi, namun allisin juga memiliki tingkat toksisitas yang cukup tinggi yang dapat merusak jaringan internal dan eksternal. Adanya pengolahan yang benar membuat senyawa yang terdapat dalam bawang putih berkurang toksiksitasnya, mengurangi rasa dan bau yang tidak diinginkan, dan meningkatkan aktivitas antioksidan dibandingkan bawang putih segar (Bae et al., 2014). Hal tersebut dikarenakan adanya inaktivasi enzim alliinase, sehingga alliin tidak diubah menjadi allisin, melainkan terjadi peningkatkan senyawa S-allyl-cysteine (SAC) yang larut di dalam air. S-allyl-cysteine merupakan salah satu senyawa yang dihasilkan dari proses aging pada bawang putih. Senyawa SAC diketahui memiliki tingkat toksisitas yang lebih rendah, tidak lebih dari $4 \%$ toksisitas allisin dan DADS (Amagase et al., 2006), dan aktivitas antioksidan yang lebih tinggi dibandingkan dengan allisin yang banyak terdapat pada bawang putih.

Bawang hitam (Black garlic) merupakan salah satu hasil proses reaksi maillard dari bawang putih dengan pemanasan dengan oven pada suhu $70{ }^{\circ} \mathrm{C}$ selama $30-40$ hari (Sasaki, 2007) tanpa adanya penambahan perlakuan atau bahan lain. Bawang hitam pertama kali dikembangkan di Jepang. Produk dari pengembangan bawang putih tersebut memiliki warna hitam dengan sedikit atau bahkan tidak ada bau yang menyengat, rasanya hampir seperti buah, dan siap untuk dapat dimakan hanya dengan mengupasnya (Wang et al, 2010). Bae et al. (2012) dalam penelitiannya menyatakan aktivitas antioksidan bawang putih memiliki kemampuan menangkal radikal DPPH sebesar $6,21 \%$, sedangkan bawang hitam 44,77\%. Suhu dan lama pemanasan dengan oven dapat mempengaruhi kadar SAC dan senyawa lain yang dihasilkan oleh produk bawang hitam (Bae, 2014).

Selain bawang hitam, pengolahan bawang putih yang sudah berkembang dan banyak dilakukan masyarakat lebih dahulu adalah bawang pickling. Pickled garlic merupakan bawang yang disimpan dalam air garam atau air cuka dalam kurun waktu tertentu. Pada umumnya dilakukan perebusan bawang putih pada air panas dengan suhu $90{ }^{\circ} \mathrm{C}$ selama 15 menit. Perebusan bertujuan untuk menginaktivasi alliinase sebelum membentuk alliin di dalam produk bawang. Adanya proses pickling pada bawang putih bertujuan terhadap inaktivasi enzim alliinase untuk menghindari efek yang tidak diinginkan, seperti flavour pedas. Sehingga diharapkan produk dapat lebih bisa diterima untuk dimanfaatkan sebagai pangan fungsional (Delaquis \& Mazza, 1998).

Penelitian ini bertujuan untuk mengetahui perbedaan proses pengolahan bawang putih (bawang hitam dan pickled garlic) terhadap nilai fungsionalnya, sehingga dapat diketahui pengolahan bawang putih mana yang lebih baik untuk dikonsumsi. Sehingga nantinya dapat dimanfaatkan sebagai bahan pangan fungsional, seperti suplemen kesehatan.

\section{METODE PENELITIAN}

Penelitian dilaksanakan di Laboratorium Bioteknologi Pangan Fakultas Teknobiologi Universitas Surabaya dari bulan Agustus 2017 sampai dengan Februari 2018. Penelitian ini dilakukan melalui dua tahap. Variabel dari penelitian tahap pertama adalah pembuatan bawang hitam dengan variasi perlakuan suhu pengovenan $\left(60^{\circ} \mathrm{C}, 70^{\circ} \mathrm{C}\right.$, dan $80^{\circ} \mathrm{C}$ ) dan lama waktu pengovenan (30 hari, 35 hari, 40 hari), dan pembuatan pickled garlic dengan variasi perlakuan kadar garam ( $2 \%, 3 \%$, dan $5 \%$ ) dan lama penyimpanan (15 hari dan 40 hari). Variabel dari penelitian tahap kedua adalah perbandingan perlakuan terbaik dari hasil pengolahan bawang hitam dan pickled garlic dengan kontrol, yaitu bawang putih.

Dalam pembuatan bawang hitam terlebih dahulu dilakukan penelitian pendahuluan dengan melakukan variasi pembungkus, yaitu sebanyak masing-masing 2 siung bawang putih utuh dibungkus menggunakan aluminium foil, tissue, dan tanpa pembungkusan. Bawang putih yang sudah dibungkus dimasukkan ke dalam oven yang diatur suhunya sebesar $37{ }^{\circ} \mathrm{C}$ selama 10 hari, kemudian dilanjutkan dengan pemanasan pada suhu $60{ }^{\circ} \mathrm{C}$ selama 30 hari. Dari hasil pendahuluan kemudian dilakukan pembuatan bawang hitam dengan masing-masing 8 siung bawang putih dimasukkan dalam oven dengan suhu sebesar $37{ }^{\circ} \mathrm{C}$ selama 10 hari, kemudian 
dilanjutkan variasi suhu $60{ }^{\circ} \mathrm{C}, 70{ }^{\circ} \mathrm{C}, 80^{\circ} \mathrm{C}$ dan variasi lama waktu 30 hari, 35 hari, dan 40 hari.

Sebanyak 50 gram bawang putih yang sudah dikupas dimasukkan ke dalam toples kaca dan diisi dengan $100 \mathrm{~mL}$ asam asetat $2 \%$ yang mengandung $\mathrm{NaCl}$ dalam beberapa konsentrasi $2 \%, 3 \%$, dan $5 \%$. Toples ditutup rapat dan dipasteurisasi selama 4 menit dalam waterbath suhu $90^{\circ} \mathrm{C}$ (Montano, 2004). Toples kemudian disimpan pada suhu $20^{\circ} \mathrm{C}$ selama 15 hari dan 40 hari.

Hasil pengolahan bawang putih (bawang hitam dan pickled garlic), yang akan dibandingkan dengan kontrol (bawang putih) digunakan sebagai sampel uji. Sebanyak 5 gram sampel dilarutkan ke dalam $45 \mathrm{~mL}$ akuades dan dihomogenkan dengan menggunakan stomacher.

Pengukuran kadar protein dilakukan dengan metode kjeldahl. Sebanyak 1 gram sampel dimasukkan ke dalam labu kjeldahl, kemudian ditambahkan 15 gram K2SO4, 1 ml larutan katalis CuSO4.5H2O atau 1 gram campuran katalis selen, batu didih, dan $25 \mathrm{ml} \mathrm{H} 2 \mathrm{SO} 4$ pekat. Campuran tersebut selanjutnya dipanaskan hingga mendidih dan larutan menjadi jernih kehijauan, kemudian didinginkan dan diencerkan dengan akuades secukupnya. Selanjutnya ditambahkan $75 \mathrm{ml}$ larutan $\mathrm{NaOH}$ 30\% lalu disulingkan selama 5 menit sampai 10 menit atau hingga larutan desilat telah mencapai kira-kira $150 \mathrm{ml}$, dengan penampung desilat adalah 50 ml larutan $\mathrm{H} 3 \mathrm{BO} 34$ \%. Campuran desilat kemudian dititrasi dengan larutan $\mathrm{HCl}$ 0,1 M. Selisih jumlah titrasi sampel dan blanko merupakan jumlah nitrogen. Kadar protein didapatkan dengan mengalikan \% $\mathrm{N}$ dengan faktor konversi.

Pengujian aktivitas antioksidan dengan reagen DPPH (2,2-diphenyl-1-picrylhydrazyl) dilakukan dengan menambahkan $1 \mathrm{ml}$ larutan sampel dengan $1 \mathrm{ml}$ reagen DPPH $(5 \mathrm{mg} / 100 \mathrm{ml}$ etanol). Blanko dibuat dengan menggunakan pelarut sampel yaitu akuades, sedangkan kontrol dibuat dari $1 \mathrm{ml}$ reagen DPPH ditambah $1 \mathrm{ml}$ pelarut sampel. Larutan diinkubasi dalam ruang gelap selama 30 menit dan kemudian dilakukan pengukuran dengan membaca serapan pada panjang gelombang $517 \mathrm{~nm}$ (Marques et al., 2012). Digunakan asam askorbat sebagai kontrol positif. Hasil uji dinyatakan dalam persentase inhibisi dengan yang didapatkan dari rumus:

$$
\% \text { Aktivitas Antioksidan }=1-\underset{\text { Absorbansi Kontrol }}{\text { (Absorbansi Sampel }}) \times 100 \%
$$

Senyawa fenolik total diuji menggunakan reagen Folin-Ciocalteau. Sebanyak $200 \mu \mathrm{l}$ sampel dengan konsentrasi $500 \mu \mathrm{g} / \mathrm{L} ; 2,5 \mathrm{ml}$ reagen Folin-Ciocalteau $10 \%$ dan $2 \mathrm{ml} \mathrm{Na} 2 \mathrm{CO} 3$ 7,5 \% dicampurkan dan diinkubasi selama 15 menit pada suhu $45{ }^{\circ} \mathrm{C}$. Absorbansi larutan kemudian diukur dengan spektrofotometer pada panjang gelombang $765 \mathrm{~nm}$. Total senyawa fenolik pada sampel bawang dinyatakan sebagai miligram ( $\mathrm{mg}$ ) asam galat ekuivalen per gram sampel (GAE/gr sampel). Sebagai standar, digunakan asam galat pada berbagai konsentrasi (50, 60, 70, 80, 90, $100 \mathrm{mg} / \mathrm{L}$ ) (Javanmardi et al., 2003). Berikut merupakan rumus perhitungan kadar fenolik total:

$$
\text { Kadar Senyawa Fenolik Total }=\frac{\text { Konsentrasi sampel }(\mathrm{ppm}) \times \text { Volume sampel }(\mathrm{L})}{\text { Berat sampel }(\mathrm{gram})}
$$

Uji aktivitas antimikroba dilakukan dengan metode agar diffusion. Biakan bakteri uji ditumbuhkan pada media nutrient broth selama 18-24 jam hingga didapatkan nilai OD600 sebesar 0,6-0,8. Suspensi bakteri yang telah disiapkan sebanyak $600 \mu \mathrm{L}$ ditambahkan ke dalam media nutrient agar (untuk $75 \mathrm{ml}$ media). Campuran kemudian dihomogenkan dan dituang ke dalam cawan petri besar steril secara aseptis, dan dibiarkan membeku. Sepuluh buah cylinder cup diletakkan di atas media dan diisi dengan sampel bawang yang sebelumnya telah dilarutkan dalam akuades. Akuades steril digunakan sebagai kontrol negatif. Kontrol positif berupa antibiotik amphicilin $(100 \mathrm{mg} / \mathrm{ml})$ untuk bakteri Escherichia coli dan Staphylococcus aureus, sedangkan chloramphenicol $(5 \mathrm{mg} / \mathrm{ml})$ untuk bakteri Salmonella typhi. Petri dibiarkan 
selama 30 menit untuk memberikan kesempatan sampel untuk berdifusi dalam media agar. Setelah itu petri diinkubasi pada suhu $37{ }^{\circ} \mathrm{C}$ selama $24-48$ jam. Zona bening yang muncul (daerah hambatan pertumbuhan bakteri) kemudian diamati dan diukur diameternya sebanyak 3 kali.

Kadar vitamin C pada sampel ditentukan dengan metode titrasi redoks (iodimetri) dengan penambahan $1 \mathrm{~mL}$ indikator amilum $1 \%(1 \mathrm{~g} / 100 \mathrm{~mL}$ akuades) pada $10 \mathrm{~mL}$ sampel bawang yang sudah dilarutkan dalam akuades. Titran yang digunakan adalah lodin 0,01 N. Titrasi dihentikan bila larutan berubah warna menjadi biru-kehitaman yang bertahan selama 1 menit, menandakan titik akhir titrasi telah tercapai. Hasil yang diperoleh dihitung dengan rumus:

Vol. titran x N I2 x Mr vit. C x 100

\author{
Kadar vitamin $\mathrm{C}=\frac{\text { Valensi vit. } \mathrm{C}}{}$
}

Perubahan warna pada sampel bawang putih dengan pengolahan diketahui dengan menggunakan alat colour reader. Sampel yang akan diukur tingkat warnanya ditera dengan sensor alat dan dilakukan pembacaan. Hasil pembacaan akan ditunjukkan dengan angka L, a, dan $b$ pada layar monitor alat. Nilai L menunjukkan tingkat kecerahan berdasarkan warna putih, nilai a menunjukkan tingkat kemerahan atau kehijauan, sedangkan nilai b menunjukkan tingkat kekuningan atau kebiruan. Nilai $L$ akan semakin positif apabila sampel semakin terang, nilai a akan semakin positif apabila sampel semakin kemerahan, sedangkan nilai $b$ akan semakin positif apabila sampel semakin kekuningan.

Pengukuran jumlah mikroba viabel dilakukan dengan total plate count. Sebanyak 0,1 $\mathrm{ml}$ sampel bawang yang telah dilarutkan dalam akuades sebelumnya, diencerkan dengan $\mathrm{NaCl}$ $0,9 \%$ secara aseptis. Kemudian dari pengenceran diambil 0,1 $\mathrm{ml}$ dan diratakan pada media PCA (Plate Count Agar) menggunakan spreader. Hasil inokulasi tersebut kemudian diinkubasi selama 24 jam pada suhu ruang. Sel yang tumbuh pada media dihitung dan jumlahnya dikalikan dengan faktor pengencerannya.

Analisis data dilakukan dengan uji statistik menggunakan software Minitab. Data diolah menggunakan uji two-way ANOVA untuk penelitian tahap pertama dan one-way ANOVA untuk penelitian tahap kedua. Tingkat kepercayaan yang digunakan yaitu $\alpha=0,05$ dengan uji lanjutan Multiple Comparison Tukey untuk data yang berbeda signifikan.

\title{
HASIL dan PEMBAHASAN \\ Hasil Pembuatan Bawang Hitam (Black Garlic)
}

Tabel 1

Hasil Pengukuran Aktivitas Antioksidan, Senyawa Fenolik Total dan Kadar Vitamin C pada Tiga Jenis Pembungkus Bawang Putih

\begin{tabular}{cccc}
\hline Parameter Uji & Tanpa & Jenis Pembungkus & \\
& $\begin{array}{c}\text { Pluminium Foil } \\
\text { Pembungkus }\end{array}$ & Tissue \\
\hline $\begin{array}{c}\text { Aktivitas Antioksidan (\% inhibisi) } \\
\text { Senyawa Fenolik Total (mg } \\
\text { GAE/g sampel) }\end{array}$ & $54,70 \pm 1,46$ & $54,70 \pm 1,46$ & $57,18 \pm 1,94$ \\
Kadar Vitamin C (\% b/b) & $0,81 \pm 0,01$ & $0,80 \pm 0,006$ & $0,82 \pm 0,002$ \\
& $0,074 \pm 0,0004$ & $0,073 \pm 0,0006$ & $0,073 \pm 0,0007$ \\
\hline
\end{tabular}

Tidak terdapat perbedaan antar perlakuan yang diberikan dengan pvalue $>0,05$. Berdasarkan hasil yang didapatkan, tidak digunakan pembungkus pada bawang putih yang digunakan dalam pembuatan bawang hitam 
Tabel 2

Hasil Uji Aktivitas Antioksidan Bawang Hitam

\begin{tabular}{cccc}
\hline & \multicolumn{3}{c}{ \% Inhibisi (\%) } \\
\hline Lama Pengovenan & \multicolumn{3}{c}{ Suhu Pengovenan $\left({ }^{\circ} \mathbf{C}\right)$} \\
& $\mathbf{6 0} \mathbf{C}$ & $\mathbf{7 0}^{\circ} \mathbf{C}$ & $\mathbf{8 0}{ }^{\circ} \mathbf{C}$ \\
30 Hari & $54,70^{\mathrm{d}} \pm 1,19$ & $63,40^{\mathrm{bc}} \pm 2,65$ & $66,76^{\mathrm{ab}} \pm 0,23$ \\
35 Hari & $57,18^{\mathrm{cd}} \pm 1,58$ & $66,11^{\mathrm{ab}} \pm 1,01$ & $63,45^{\mathrm{bc}} \pm 0,54$ \\
40 Hari & $61,05^{\mathrm{bcd}} \pm 0,49$ & $63,86^{\mathrm{bc}} \pm 0,47$ & $72,30^{\mathrm{a}} \pm 0,85$ \\
\hline
\end{tabular}

*) Huruf di belakang angka rata-rata yang berbeda menunjukkan perbedaan signifikan berdasarkan uji statistik dengan $\alpha=0,05$

Persentase inhibisi radikal DPPH tertinggi yaitu bawang hitam dengan perlakuan suhu $80^{\circ} \mathrm{C}$ selama 40 hari pengovenan, sedangkan persentase terendah yaitu pada perlakuan suhu $60{ }^{\circ} \mathrm{C}$ selama 30 hari. Bae et al. (2014) dalam penelitiannya menyatakan kemampuan penangkal radikal DPPH secara signifikan meningkat seiring dengan peningkatan temperatur dari 40 ke $85{ }^{\circ} \mathrm{C}$. Woo et al. (2007) meneliti tentang efek ekstrak bawang terhadap kemampuan donor elektron kepada radikal DPPH dalam variasi suhu tertentu dimana kemampuan donor elektron (\%) dari ekstrak bawang secara bertahap mengalami peningkatan seiring dengan peningkatan suhu dari 100 hingga $120^{\circ} \mathrm{C}$, sehingga dinyatakan kemampuan donor elektron (\%) rendah pada suhu rendah dan meningkat pada suhu yang lebih tinggi. Selain kemampuan donor elektron, peningkatan aktivitas penangkalan radikal DPPH juga dapat dipengaruhi karena adanya kandungan SAC (S-allyl cysteine) yang diduga bertanggung jawab dalam aktivitas antioksidan sampel bawang hitam untuk menginhibisi radikal bebas (Borek, 2001) yang terjadi karena tidak adanya penghancuran atau pemotongan, sehingga enzim allinase tidak bereaksi untuk memproduksi allinase dari senyawa allin yang ada dalam bawang putih melainkan terjadi pembentukan senyawa SAC (Jones et al., 2007). Beberapa produk dari reaksi browning dalam reaksi maillard yang terjadi pada produk bawang hitam juga dapat menyebabkan peningkatan aktivitas antioksidan dengan cara memutuskan rantai radikal bebas melalui pendonoran atom hidrogen (Manzocco et al., 2000).

Tabel 3

Hasil Uji Senyawa Fenolik Total Bawang Hitam

\begin{tabular}{cccc}
\hline & \multicolumn{3}{c}{ Konsentrasi (mg GAE/g sampel) } \\
\hline Lama Pengovenan & $\mathbf{6 0}$ & Suhu Pengovenan $\left({ }^{\circ} \mathbf{C}\right)$ \\
& $0,81^{\mathrm{f}} \pm 0,01$ & $\mathbf{7 0}$ & $\mathbf{8 0}$ \\
$\mathbf{3 0}$ Hari & $0,82^{\mathrm{f}} \pm 0,01$ & $1,07^{\mathrm{c}} \pm 0,01$ & $1,20^{\mathrm{a}} \pm 0,03$ \\
$\mathbf{3 5}$ Hari & $0,85^{\mathrm{f}} \pm 0,02$ & $0,92^{\mathrm{e}} \pm 0,01$ & $1,15^{\mathrm{b}} \pm 0,02$ \\
40 Hari & $0,98^{\mathrm{d}} \pm 0,01$ & $1,09^{\mathrm{bc}} \pm 0,01$ \\
\hline
\end{tabular}

*) Huruf di belakang angka rata-rata yang berbeda menunjukkan perbedaan signifikan berdasarkan uji statistik dengan $\alpha=0,05$

Total senyawa fenolik tertinggi yaitu bawang hitam dengan perlakuan suhu $80{ }^{\circ} \mathrm{C}$ selama 30 hari pengovenan, sedangkan total senyawa fenolik terendah yaitu pada perlakuan suhu $60^{\circ} \mathrm{C}$ selama 30 hari. Adanya pemanasan pada senyawa fenolik meningkatkan kandungan fenol bebas karena berkurangnya ester, glikosida, dan ikatan ester (Xu et al., 2007). Penurunan senyawa fenolik total yang terjadi pada perlakuan suhu $70{ }^{\circ} \mathrm{C}$ selama 35 hari dan suhu $80{ }^{\circ} \mathrm{C}$ selama 35 hari (Tabel 3) dapat disebabkan karena lama waktu selama pemanasan dapat mempengaruhi kandungan bioaktif, seperti polifenol dan flavonoid (Gorinstein et al., 2008). Perlakuan panas memiliki pengaruh yang besar terhadap availibilitas flavonoid tergantung dari lama waktu perlakuan, sensitivitas terhadap panas, dan lingkungan fisikokimia bahan pangan (loannou et al., 2012). 
Tabel 4

Hasil Uji Kadar Vitamin C Bawang Hitam

\begin{tabular}{cccc}
\hline & \multicolumn{3}{c}{ Kadar Vitamin C (\% b/b) } \\
\hline Lama Pengovenan & $\mathbf{6 0}$ & \multicolumn{3}{c}{ Suhu Pengovenan $\left({ }^{\circ} \mathbf{C}\right)$} \\
30 Hari & $0,07^{\mathrm{f}} \pm 0,0037$ & $\mathbf{7 0}$ & $\mathbf{8 0}$ \\
35 Hari & $0,12^{\mathrm{e}} \pm 0,0029$ & $0,13^{\mathrm{e}} \pm 0,0068$ & $0,21^{\mathrm{c}} \pm 0,012$ \\
40 Hari & $0,12^{\mathrm{e}} \pm 0,0060$ & $0,28^{\mathrm{b}} \pm 0,0068$ & $0,29^{\mathrm{b}} \pm 0,0094$ \\
\end{tabular}

*) Huruf di belakang angka rata-rata yang berbeda menunjukkan perbedaan signifikan berdasarkan uji statistik dengan $\alpha=0,05$

Kadar vitamin $\mathrm{C}$ tertinggi yaitu bawang hitam dengan perlakuan suhu $80^{\circ} \mathrm{C}$ selama 40 hari pengovenan, sedangkan kadar terendah yaitu pada perlakuan suhu $60^{\circ} \mathrm{C}$ selama 30 hari. Kim et al. (2012) dalam penelitiannya menyatakan adanya proses pemanasan memberikan pengaruh terhadap meningkatnya vitamin larut air (termasuk vitamin C) hingga 1,15 sampai 1,92 kali bawang putih biasa, namun menurunkan vitamin larut lemak.

Tabel 5

Hasil Analisa Senyawa Antimikroba Bawang Hitam pada Escherichia coli

\begin{tabular}{cccc}
\hline & \multicolumn{3}{c}{ Daerah Hambat $(\mathbf{m m})$} \\
\hline Lama Pengovenan & $\mathbf{6 0}$ & \multicolumn{2}{c}{ Suhu Pengovenan $\left({ }^{\circ} \mathbf{C}\right)$} \\
30 Hari & $11,4^{\mathrm{c}} \pm 0,00$ & $\mathbf{7 0}$ & $\mathbf{8 0}$ \\
$\mathbf{3 5 ~ H a r i}$ & $11,4^{\mathrm{c}} \pm 0,05$ & $12,6^{\mathrm{b}} \pm 0,41$ & $12,4^{\mathrm{b}} \pm 0,12$ \\
$\mathbf{4 0}$ Hari & $11,0^{\mathrm{c}} \pm 0,19$ & $11,7^{\mathrm{b}} \pm 0,13$ & $12,6^{\mathrm{b}} \pm 0,27$ \\
Kontrol + & & $12,8^{\mathrm{b}} \pm 0,45$ & $12,5^{\mathrm{b}} \pm 0,13$ \\
Kontrol - & \multicolumn{3}{c}{$16,0^{\mathrm{a}} \pm 0,83$} \\
\end{tabular}

*) Huruf di belakang angka rata-rata yang berbeda menunjukkan perbedaan signifikan berdasarkan uji statistik dengan $\alpha=0,05$

**) Kontrol positif menggunakan antibiotik ampisilin $100 \mathrm{mg} / \mathrm{mL}$ dan kontrol negatif menggunakan pelarut sampel (akuades) steril

Tabel 6

Hasil Analisa Senyawa Antimikroba Bawang Hitam pada Staphylococcus aureus

\begin{tabular}{|c|c|c|c|}
\hline \multirow{3}{*}{ Lama Pengovenan } & \multicolumn{3}{|c|}{ Daerah Hambat (mm) } \\
\hline & \multicolumn{3}{|c|}{ Suhu Pengovenan $\left({ }^{\circ} \mathrm{C}\right)$} \\
\hline & 60 & 70 & 80 \\
\hline 30 Hari & $10,5^{c} \pm 0,79$ & $11,3^{c} \pm 0,33$ & $12,5^{b} \pm 0,29$ \\
\hline 35 Hari & $11,2^{c} \pm 0,62$ & $11,2^{c} \pm 0,16$ & $12,4^{b} \pm 0,25$ \\
\hline 40 Hari & $11,7^{c} \pm 0,36$ & $11,0^{c} \pm 0,29$ & $12,0^{b} \pm 0,28$ \\
\hline Kontrol + & \multicolumn{3}{|c|}{$15,6^{\mathrm{a}} \pm 0,76$} \\
\hline Kontrol - & \multicolumn{3}{|c|}{$8,3^{d} \pm 0,19$} \\
\hline
\end{tabular}

*) Huruf di belakang angka rata-rata yang berbeda menunjukkan perbedaan signifikan berdasarkan uji statistik dengan $\alpha=0,05$

${ }^{* *}$ ) Kontrol positif menggunakan antibiotik ampisilin $100 \mathrm{mg} / \mathrm{mL}$ dan kontrol negatif menggunakan pelarut sampel (akuades) steril 
Tabel 7

Hasil Analisa Senyawa Antimikroba Bawang Hitam pada Salmonella typhi

\begin{tabular}{|c|c|c|c|}
\hline \multirow{3}{*}{ Lama Pengovenan } & \multicolumn{3}{|c|}{ Daerah Hambat (mm) } \\
\hline & \multicolumn{3}{|c|}{ Suhu Pengovenan $\left({ }^{\circ} \mathrm{C}\right)$} \\
\hline & 60 & 70 & 80 \\
\hline 30 Hari & $12,3 \pm 0,26$ & $12,2 \pm 0,39$ & $12,6 \pm 0,36$ \\
\hline 35 Hari & $12,4 \pm 0,39$ & $12,3 \pm 0,21$ & $12,1 \pm 0,22$ \\
\hline 40 Hari & $12,1 \pm 0,13$ & $13,1 \pm 0,46$ & $12,5 \pm 0,49$ \\
\hline $\begin{array}{l}\text { Kontrol + } \\
\text { Kontrol - }\end{array}$ & & \multicolumn{2}{|c|}{$\begin{array}{c}42,2 \pm 0,86 \\
8,3 \pm 0,60\end{array}$} \\
\hline
\end{tabular}

*) Huruf di belakang angka rata-rata yang berbeda menunjukkan perbedaan signifikan berdasarkan uji statistik dengan $\alpha=0,05$

${ }^{* *}$ ) Kontrol positif menggunakan antibiotik kloramfenikol $5 \mathrm{mg} / \mathrm{mL}$ dan kontrol negatif menggunakan pelarut sampel (akuades) steril

Adanya aktivitas antimikroba dalam bawang hitam tidak hanya didapatkan dari kandungan allisin yang masih terdapat dalam bawang hitam, namun juga dapat berasal dari kandungan senyawa fenolik. Perbedaan antar perlakuan yang tidak terlalu tampak dapat disebabkan karena kurangnya produksi allisin yang memiliki daya antimikroba lebih tinggi dibandingkan SAC dan pelarut yang digunakan kurang baik, sehingga hasil yang diberikan kurang maksimal

Tabel 8

Hasil Uji Kadar Protein Bawang Hitam

\begin{tabular}{cccc}
\hline & \multicolumn{3}{c}{ Kadar Protein (\% N) } \\
\hline Lama Pengovenan & $\mathbf{6 0}$ & \multicolumn{3}{c}{ Suhu Pengovenan $\left({ }^{\circ} \mathbf{C}\right)$} \\
30 Hari & $10,79^{\mathrm{a}} \pm 0,47$ & $\mathbf{7 0}$ & $\mathbf{8 0}$ \\
35 Hari & $10,12^{\mathrm{abc}} \pm 0,09$ & $9,83^{\mathrm{abc}} \pm 0,14$ & $10,45^{\mathrm{ab}} \pm 0,71$ \\
$\mathbf{4 0}$ Hari & $9,80^{\mathrm{abcd}} \pm 0,03$ & $8,53^{\mathrm{bcd}} \pm 0,07$ & $8,91^{\mathrm{cd}} \pm 0,35$ \\
& & $8,57^{\mathrm{de}} \pm 0,38$ & $7,61^{\mathrm{e}} \pm 0,38$ \\
\hline
\end{tabular}

*) Huruf di belakang angka rata-rata yang berbeda menunjukkan perbedaan signifikan berdasarkan uji statistik dengan $\alpha=0,05$

Kadar protein tertinggi yaitu bawang hitam dengan perlakuan suhu $60{ }^{\circ} \mathrm{C}$ selama 30 hari pengovenan, sedangkan kadar protein terendah yaitu pada perlakuan suhu $80{ }^{\circ} \mathrm{C}$ selama 40 hari. Peningkatan kadar protein yang terjadi dapat disebabkan karena adanya senyawa $\mathrm{N}$ pada berbagai senyawa yang terkandung dalam bawang hitam yaitu senyawa S-allil sistein (SAC) dan S-allil merkaptosistein (SAMC), sehingga semakin tinggi kandungan kedua senyawa tersebut dapat meningkatkan hasil deteksi metode Kjeldahl. Dalam reaksi maillard pigmen coklat (hasil browing) terikat secara kovalen kepada protein (Brands et al., 2002). Terjadinya penurunan kadar protein dapat disebabkan karena protein yang ada digunakan sebagai bahan baku reaksi maillard. Manley (2011) menyatakan suhu dapat mempengaruhi reaksi maillard, dimana semakin tinggi suhu lingkungan, reaksi maillard semakin meningkat.

Tabel 9

Hasil Uji Jumlah Mikroba Viable Bawang Hitam

\begin{tabular}{cccc}
\hline & \multicolumn{3}{c}{ Jumlah Koloni $(\log$ CFU/mL) } \\
\hline Lama Pengovenan & $\mathbf{6 0}$ & \multicolumn{2}{c}{ Suhu Pengovenan $\left({ }^{\circ} \mathbf{C}\right)$} \\
30 Hari & $2,36^{\mathrm{a}} \pm 0,08$ & $\mathbf{7 0}$ & $\mathbf{8 0}$ \\
35 Hari & $2,10^{\mathrm{a}} \pm 0,14$ & $0,67^{\mathrm{b}} \pm 0,94$ & $0,00^{\mathrm{b}} \pm 0,00$ \\
40 Hari & $0,77^{\mathrm{a}} \pm 1,09$ & $0,00^{\mathrm{b}} \pm 0,00$ & $0,00^{\mathrm{b}} \pm 0,00$ \\
& $0,00^{\mathrm{b}} \pm 0,00$ & $0,00^{\mathrm{b}} \pm 0,00$ \\
\hline
\end{tabular}

*) Huruf di belakang angka rata-rata yang berbeda menunjukkan perbedaan signifikan berdasarkan uji statistik dengan $\alpha=0,05$ 
Hasil uji membuktikan bahwa pembuatan bawang hitam dalam metode ini bukan merupakan fermentasi yang memanfaatkan mikroba, namun adanya reaksi browing nonenzimatis yang dinamakan reaksi maillard karena suhu yang digunakan dalam proses pembuatan lebih tinggi dari $70{ }^{\circ} \mathrm{C}$ (Wang et al., 2010). Dengan suhu seperti itu, tidak terdapat pertumbuhan bakteri untuk dapat melakukan fermentasi, sehingga tidak lagi ditemukan pertumbuhan Lactobacillus dalam inkubasi bawang hitam (Sasaki et al., 2007).

Tabel 10

Hasil Uji Warna Sampel Bawang Hitam

\begin{tabular}{ccccc}
\hline \multicolumn{2}{c}{ Perlakuan } \\
Suhu $\left({ }^{\circ} \mathbf{C}\right.$ ) & Waktu (Hari) & L & a & Nilai \\
\hline \multicolumn{2}{c}{ Bawang Putih } & $108,2 \pm 0,16$ & $1,8 \pm 0,09$ & $39,13 \pm 0,26$ \\
& $\mathbf{3 0}$ & $41,33^{\mathrm{a}} \pm 0,05$ & $9,13^{\mathrm{a}} \pm 0,13$ & $13,13^{\mathrm{a}} \pm 0,09$ \\
$\mathbf{6 0}$ & $\mathbf{3 5}$ & $39,90^{\mathrm{b}} \pm 0,00$ & $8,37^{\mathrm{b}} \pm 0,05$ & $12,43^{\mathrm{b}} \pm 0,13$ \\
& $\mathbf{4 0}$ & $35,20^{\mathrm{c}} \pm 0,16$ & $8,23^{\mathrm{b}} \pm 0,13$ & $10,40^{\mathrm{c}} \pm 0,14$ \\
& $\mathbf{3 0}$ & $31,97^{\mathrm{d}} \pm 0,13$ & $6,43^{\mathrm{c}} \pm 0,17$ & $8,47^{\mathrm{d}} \pm 0,21$ \\
$\mathbf{7 0}$ & $\mathbf{3 5}$ & $30,37^{\mathrm{e}} \pm 0,21$ & $6,40^{\mathrm{cd}} \pm 0,00$ & $8,27^{\mathrm{d}} \pm 0,13$ \\
& $\mathbf{4 0}$ & $28,40^{\mathrm{f}} \pm 0,22$ & $6,07^{\mathrm{d}} \pm 0,05$ & $8,30^{\mathrm{d}} \pm 0,14$ \\
& $\mathbf{3 0}$ & $26,27^{\mathrm{g}} \pm 0,13$ & $4,37^{\mathrm{e}} \pm 0,05$ & $5,57^{\mathrm{e}} \pm 0,05$ \\
$\mathbf{8 0}$ & $\mathbf{3 5}$ & $24,47^{\mathrm{h}} \pm 0,05$ & $3,53^{\mathrm{f}} \pm 0,05$ & $5,40^{\mathrm{e}} \pm 0,08$ \\
& $\mathbf{4 0}$ & $23,57^{\mathrm{i}} \pm 0,05$ & $2,33^{\mathrm{g}} \pm 0,13$ & $4,37^{\mathrm{f}} \pm 0,05$ \\
\hline
\end{tabular}

*) Huruf di belakang angka rata-rata yang berbeda menunjukkan perbedaan signifikan berdasarkan uji statistik dengan $\alpha=0,05$ (pada kolom yang sama)

Warna dari bawang hitam yang paling gelap yaitu bawang hitam dengan perlakuan suhu $80{ }^{\circ} \mathrm{C}$ selama 40 hari pengovenan, sedangkan yang paling terang yaitu pada perlakuan suhu $60{ }^{\circ} \mathrm{C}$ selama 30 hari. Nilai L yang jauh lebih rendah dibandingkan bawang putih menunjukkan tingkat kecerahan bawang hitam sangat kecil. Selain itu, nilai a dan b yang semakin kecil seiring dengan meningkatnya suhu dan lama waktu pengovenan menunjukkan warna yang dimiliki bawang hitam semakin mengarah ke gelap. Warna gelap berwarna coklat kehitaman disebabkan karena adanya reaksi maillard yang dapat dipengaruhi oleh suhu. Reaksi maillard merupakan reaksi kunci dari pembuatan bawang hitam, yang menyebabkan terjadinya pencoklatan atau disebut non-enzymatic browning

\section{Hasil Pembuatan Pickled Garlic}

Tabel 11

Hasil Uji Aktivitas Antioksidan Pickled Garlic

\begin{tabular}{rccc}
\hline & \multicolumn{2}{c}{ \% Inhibisi (\%) } \\
\hline Lama & \multicolumn{2}{c}{ Kadar Garam (\% b/v) } \\
Penyimpanan & $\mathbf{2}$ & $\mathbf{3}$ & $\mathbf{5}$ \\
$\mathbf{1 5}$ Hari & $16,32^{\mathrm{d}} \pm 0,99$ & $16,83^{\mathrm{d}} \pm 0,55$ & $21,03^{\mathrm{c}} \pm 1,5$ \\
$\mathbf{4 0}$ Hari & $27,52^{\mathrm{b}} \pm 0,33$ & $32,17^{\mathrm{a}} \pm 1,31$ & $22,01^{\mathrm{c}} \pm 1,66$ \\
\hline
\end{tabular}

*) Huruf di belakang angka rata-rata yang berbeda menunjukkan perbedaan signifikan berdasarkan uji statistik dengan $\alpha=0,05$

Persentase inhibisi radikal DPPH tertinggi yaitu pickled garlic dengan perlakuan kadar garam $3 \%$ selama 40 hari penyimpanan, sedangkan persentase terendah yaitu pada perlakuan kadar garam $2 \%$ selama 15 hari penyimpanan. Hasil penelitian memperlihatkan bahwa semakin tinggi kadar garam dan semakin lama waktu penyimpanan, aktivitas antioksidan yang dihasilkan semakin meningkat. Semakin lama waktu penyimpanan, semakin banyak SAC yang dihasilkan. SAC merupakan komponen organosulfur penting dalam bawang yang larut dalam air (Jones et al., 2007). Peningkatan SAC terjadi karena dalam pembuatan pickled garlic, bawang putih tetap dibiarkan utuh tanpa adanya proses pemotongan yang dapat 
menyebabkan enzim allinase bereaksi untuk mengubah allin menjadi allinase dan terjadi inaktivasi enzim allinase dengan adanya perlakuan blanching pada suhu $90{ }^{\circ} \mathrm{C}$ selama 5 menit (Rejano et al., 1997).

Tabel 12

Hasil Uji Senyawa Fenolik Total Pickled Garlic

\begin{tabular}{cccc}
\hline & \multicolumn{2}{c}{ Konsentrasi (mg GAE/g sampel) } \\
\hline Lama & \multicolumn{2}{c}{ Kadar Garam (\%) b/v) } \\
Penyimpanan & $\mathbf{2}$ & $\mathbf{3}$ & $\mathbf{5}$ \\
15 Hari & $0,10^{\mathrm{d}} \pm 0,0076$ & $0,12^{\mathrm{c}} \pm 0,0031$ & $0,11^{\mathrm{d}} \pm 0,0031$ \\
40 Hari & $0,14^{\mathrm{ab}} \pm 0,0019$ & $0,15^{\mathrm{a}} \pm 0,0005$ & $0,13^{\mathrm{bc}} \pm 0,0039$ \\
\hline
\end{tabular}

*) Huruf di belakang angka rata-rata yang berbeda menunjukkan perbedaan signifikan berdasarkan uji statistik dengan $\alpha=0,05$

Total senyawa fenolik tertinggi yaitu pickled garlic dengan perlakuan kadar garam 3\% selama 40 hari penyimpanan, sedangkan total senyawa fenolik terendah yaitu pada perlakuan kadar garam 2\% selama 15 hari penyimpanan. Sayin dan Alkan (2015) dalam penelitian menguji senyawa fenolik dan aktivitas antioksidan berbagai sayuran yang di-pickled menyatakan adanya peningkatan senyawa fenolik setelah 15 hari proses penyimpanan hingga 60 hari. Peningkatan senyawa fenolik ini dapat disebabkan setelah adanya fermentasi asam laktat dari sayuran tersebut. Kadar garam memberikan pengaruh terhadap $\mathrm{pH}$ yang merupakan salah satu parameter penting untuk mempengaruhi jumlah dan perubahan struktur fitokimia selama proses pickling berlangsung.

Tabel 13 Hasil Uji Kadar Vitamin C Pickled Garlic

\begin{tabular}{rccc}
\hline & \multicolumn{3}{c}{ Kadar Vitamin C (\% b/b) } \\
\hline Lama & \multicolumn{2}{c}{ Kadar Garam (\%b/v) } \\
Penyimpanan & $\mathbf{2}$ & $\mathbf{3}$ & $\mathbf{5}$ \\
15 Hari & $0,04^{\mathrm{bc}} \pm 0,0054$ & $0,03^{\mathrm{c}} \pm 0,0029$ & $0,04^{\mathrm{c}} \pm 0,0022$ \\
40 Hari & $0,06^{\mathrm{a}} \pm 0,0037$ & $0,05^{\mathrm{b}} \pm 0,0054$ & $0,04^{\mathrm{bc}} \pm 0,0054$ \\
\hline
\end{tabular}

*) Huruf di belakang angka rata-rata yang berbeda menunjukkan perbedaan signifikan berdasarkan uji statistik dengan $\alpha=0,05$

Kadar vitamin C tertinggi yaitu pickled garlic dengan perlakuan kadar garam $2 \%$ selama 40 hari penyimpanan, sedangkan kadar vitamin $C$ terendah yaitu pada perlakuan kadar garam $3 \%$ selama 15 hari penyimpanan. Penurunan kandungan asam askorbat atau vitamin $\mathrm{C}$ selama proses pickling dapat dipengaruhi dengan adanya proses perebusan atau blanching $\left(90{ }^{\circ} \mathrm{C}\right.$ selama 4 menit dalam penelitian), metode preservasi, lama penyimpanan, dan kandungan larutan penyimpanan yang dapat mempengaruhi komposisi vitamin dan asam amino (Montano et al., 2004). Terjadinya over-blanching diketahui dapat menyebabkan hilangnya nutrien dan tekstur (Rejano et al., 2004).

Tabel 14

Hasil Analisa Senyawa Antimikroba Pickled Garlic pada Escherichia coli

\begin{tabular}{cccc}
\hline & \multicolumn{4}{c}{ Daerah Hambat (mm) } \\
\hline Lama & $\mathbf{3}$ Kadar Garam (\% b/v) \\
Penyimpanan & $\mathbf{2}$ & $\mathbf{3}$ & $\mathbf{5}$ \\
$\mathbf{1 5}$ Hari & $11,7 \pm 0,31$ & $12,5 \pm 0,26$ & $12,2 \pm 0,45$ \\
$\mathbf{4 0}$ Hari & $12,5 \pm 0,54$ & $12,1 \pm 0,21$ & $12,0 \pm 0,58$ \\
Kontrol + & & \multicolumn{3}{c}{$12,8 \pm 0,24$} \\
Kontrol - & \multicolumn{3}{c}{$8,4 \pm 0,65$} \\
\hline
\end{tabular}

**) Kontrol positif menggunakan antibiotik ampisilin $100 \mathrm{mg} / \mathrm{mL}$ dan kontrol negatif menggunakan pelarut sampel (akuades) steril 
Tabel 15

Hasil Analisa Senyawa Antimikroba Pickled Garlic pada Staphylococcus aureus

\begin{tabular}{cccc}
\hline & \multicolumn{3}{c}{ Daerah Hambat (mm) } \\
\hline Lama & \multicolumn{3}{c}{ Kadar Garam (\% b/v) } \\
Penyimpanan & $\mathbf{2}$ & $\mathbf{3}$ & $\mathbf{5}$ \\
$\mathbf{1 5}$ Hari & $12,4 \pm 0,25$ & $12,2 \pm 0,28$ & $11,9 \pm 0,13$ \\
$\mathbf{4 0}$ Hari & $12,6 \pm 0,09$ & $12,1 \pm 0,17$ & 0,29 \\
Kontrol + & \multicolumn{3}{c}{$15,6 \pm 0,76$} \\
Kontrol - & \multicolumn{3}{c}{$8,3 \pm 0,19$} \\
\hline
\end{tabular}

*) Kontrol positif menggunakan antibiotik ampisilin $100 \mathrm{mg} / \mathrm{mL}$ dan kontrol negatif menggunakan pelarut sampel (akuades) steril

Tabel 16

Hasil Analisa Senyawa Antimikroba Pickled Garlic pada Salmonella typhi

\begin{tabular}{cccc}
\hline & \multicolumn{3}{c}{ Daerah Hambat (mm) } \\
\hline Lama & \multicolumn{3}{c}{ Kadar Garam (\% b/v) } \\
Penyimpanan & $\mathbf{2}$ & $\mathbf{3}$ & $\mathbf{5}$ \\
$\mathbf{1 5}$ Hari & $12,4 \pm 0,25$ & $12,2 \pm 0,22$ & $12,6 \pm 0,26$ \\
$\mathbf{4 0 ~ H a r i ~}$ & $12,1 \pm 0,17$ & $12,2 \pm 0,25$ & $12,4 \pm 0,22$ \\
Kontrol + & & \multicolumn{3}{c}{$42,2 \pm 0,86$} \\
Kontrol - & & \multicolumn{3}{c}{$8 \pm 0,60$}
\end{tabular}

*) Kontrol positif menggunakan antibiotik kloramfenikol $5 \mathrm{mg} / \mathrm{mL}$ dan kontrol negatif menggunakan pelarut sampel (akuades) steril

Aktivitas antimikroba pickled garlic tidak hanya didapatkan dari kandungan allisin yang masih terdapat dalam bawang pickled, namun juga berasal dari kandungan senyawa fenolik yang dihasilkan selama proses penyimpanan. Perlakuan kadar garam dan lama penyimpanan yang tidak memberikan cukup perbedaan dapat disebabkan karena pemakaian jenis pelarut kurang baik, sehingga hasil yang diberikan kurang maksimal.

Tabel 17

Hasil Uji Kadar Protein Pickled Garlic

\begin{tabular}{rccc}
\hline & \multicolumn{3}{c}{ Kadar Protein (\% N) } \\
\hline Lama & \multicolumn{2}{c}{ Kadar Garam (\%b/v) } \\
Penyimpanan & $\mathbf{2}$ & $\mathbf{3}$ & $\mathbf{5}$ \\
$\mathbf{1 5}$ Hari & $1,42^{\mathrm{a}} \pm 0,037$ & $1,44^{\mathrm{a}} \pm 0,029$ & $1,27^{\mathrm{b}} \pm 0,025$ \\
$\mathbf{4 0}$ Hari & $1,45^{\mathrm{a}} \pm 0,037$ & $1,60^{\mathrm{a}} \pm 0,045$ & $1,15^{\mathrm{b}} \pm 0,013$ \\
\hline
\end{tabular}

*) Huruf di belakang angka rata-rata yang berbeda menunjukkan perbedaan signifikan berdasarkan uji statistik dengan $\alpha=0,05$ (pada satu kolom yang sama)

Kadar protein tertinggi yaitu pickled garlic dengan perlakuan kadar garam $3 \%$ selama 40 hari penyimpanan, sedangkan kadar protein terendah yaitu pada perlakuan kadar garam $5 \%$ selama 40 hari penyimpanan. Kadar protein yang cukup rendah dapat dikarenakan kandungan senyawa lain seperti SAC yang mengandung komponen $\mathrm{N}$ juga cukup rendah. Selain itu, adanya proses blanching saat preparasi juga dapat merusak protein yang terkandung dalam bawang putih.

Tabel 18 Hasil Uji Jumlah Mikroba Viable Pickled Garlic

\begin{tabular}{cccc}
\hline & \multicolumn{3}{c}{ Jumlah Koloni (log CFU/mL) } \\
\hline Lama & \multicolumn{2}{c}{ Kadar Garam (\%b/v) } \\
Penyimpanan & $\mathbf{2}$ & $\mathbf{3}$ & $\mathbf{5}$ \\
$\mathbf{1 5}$ Hari & $1,64^{\mathrm{a}} \pm 1,16$ & $0,00^{\mathrm{a}} \pm 0,00$ & $0,00^{\mathrm{a}} \pm 0,00$ \\
40 Hari & $0,00^{\mathrm{a}} \pm 0,00$ & $0,00^{\mathrm{a}} \pm 0,00$ & $0,00^{\mathrm{a}} \pm 0,00$ \\
\hline
\end{tabular}

*) Huruf di belakang angka rata-rata yang berbeda menunjukkan perbedaan signifikan berdasarkan uji statistik dengan $\alpha=0,05$ 
Tidak adanya peran mikroorganisme dalam pembuatan pickled garlic dalam penelitian ini, sehingga tidak terjadi fermentasi selama penyimpanan. Tidak adanya mikroorganisme yang tumbuh dapat dikarenakan tingginya kadar asam asetat dan kadar garam yang dihasilkan sehingga menghasilkan $\mathrm{pH}$ yang asam $( \pm 2-3,5)$ untuk dapat menjadi media tumbuhnya mikroorganisme.

Tabel 19

Hasil Uji Warna Pickled Garlic

\begin{tabular}{|c|c|c|c|c|}
\hline \multicolumn{3}{|c|}{ Perlakuan } & \multicolumn{2}{|c|}{ Nilai } \\
\hline $\begin{array}{l}\text { Kadar Garam (\% } \\
\text { b/v) }\end{array}$ & Waktu (Hari) & $\mathbf{L}$ & a & b \\
\hline \multicolumn{2}{|c|}{ Bawang Putih } & $108,2 \pm 0,16$ & $1,8 \pm 0,09$ & $39,13 \pm 0,26$ \\
\hline \multirow{2}{*}{2} & 15 & $106,43 \pm 0,21$ & $2,23 \pm 0,05$ & $40,23 \pm 0,13$ \\
\hline & 40 & $106,13 \pm 0,13$ & $2,13 \pm 0,17$ & $40,13 \pm 0,17$ \\
\hline \multirow{2}{*}{3} & 15 & $106,50 \pm 0,09$ & $2,43 \pm 0,09$ & $40,23 \pm 0,13$ \\
\hline & 40 & $106,27 \pm 0,16$ & $2,23 \pm 0,17$ & $39,97 \pm 0,05$ \\
\hline \multirow{2}{*}{5} & 15 & $106,50 \pm 0,28$ & $2,47 \pm 0,16$ & $40,33 \pm 0,17$ \\
\hline & 40 & $106,47 \pm 0,09$ & $2,30 \pm 0,05$ & $40,33 \pm 0,13$ \\
\hline
\end{tabular}

Nilai a dan b pada pickled garlic mengalami peningkatan (produk menjadi lebih kuning), sedangkan nilai L mengalami penurunan (produk kehilangan kecerahan). Adanya proses blanching menghentikan terjadinya perubahan warna pada pickled garlic, sehingga hasil uji warna tidak jauh berbeda dengan bawang putih (Casado et al., 2004).

\section{Hasil Penentuan Pengolahan Terbaik}

Berdasarkan hasil uji yang didapatkan dari seluruh variasi pengolahan, diambil masing - masing satu variasi pengolahan terbaik dari bawang hitam dan pickled garlic untuk dibandingkan dengan kontrol, yaitu bawang putih tanpa pengolahan. Pada bawang hitam diambil pengolahan suhu $80{ }^{\circ} \mathrm{C}$ dengan lama waktu pengovenan 40 hari, sedangkan pada pickled garlic diambil pengolahan kadar garam $3 \%(b / v)$ dengan lama waktu penyimpanan 40 hari.

\section{Tabel 20}

Perbandingan Bawang Putih, Bawang Hitam, dan Pickled Garlic

\begin{tabular}{cccc}
\hline Hasil Uji & \multicolumn{2}{c}{ Jenis Sampel } \\
& Bawang Putih & Black Garlic & Pickled Garlic \\
\hline Aktivitas Antioksidan (\% inhibisi) & $37,03^{\mathrm{b}} \pm 2,16$ & $72,30^{\mathrm{a}} \pm 0,83$ & $32,17^{\mathrm{c}} \pm 1,31$ \\
$\quad \begin{array}{c}\text { Senyawa Fenolik Total (mg } \\
\text { GAE/g sampel) }\end{array}$ & $0,50^{\mathrm{b}} \pm 0,05$ & $1,09^{\mathrm{a}} \pm 0,03$ & $0,146^{\mathrm{c}} \pm 0,001$ \\
$\quad$ Kadar Vitamin C (\% b/b) & $0,068^{\mathrm{b}} \pm 0,004$ & $0,348^{\mathrm{a}} \pm 0,006$ & $0,054^{\mathrm{b}} \pm 0,006$ \\
$\begin{array}{c}\text { Senyawa Antimikroba pada } \\
\quad \text { Escherichia coli }\end{array}$ & $12,7^{\mathrm{a}} \pm 0,22$ & $12,5^{\mathrm{a}} \pm 0,13$ & $12,1^{\mathrm{a}} \pm 0,21$ \\
$\quad \begin{array}{c}\text { Senyawa Antimikroba pada } \\
\text { Staphylococcus aureus }\end{array}$ & $11,6^{\mathrm{a}} \pm 0,48$ & $12,0^{\mathrm{a}} \pm 0,28$ & $12,1^{\mathrm{a}} \pm 0,17$ \\
$\quad \begin{array}{c}\text { Senyawa Antimikroba pada } \\
\text { Salmonella typhi }\end{array}$ & $12,8^{\mathrm{a}} \pm 0,22$ & $12,5^{\mathrm{a}} \pm 0,45$ & $12,2^{\mathrm{a}} \pm 0,25$ \\
$\quad \begin{array}{c}\text { Kadar Protein (\% N) } \\
\text { Total Plate Count }\end{array}$ & $3,1^{\mathrm{b}} \pm 0,082$ & $7,61^{\mathrm{a}} \pm 0,376$ & $1,45^{\mathrm{c}} \pm 0,037$ \\
& $3,03^{\mathrm{a}} \pm 0,020$ & $0,00^{\mathrm{a}} \pm 0,00$ & $0,00^{\mathrm{a}} \pm 0,00$ \\
\hline
\end{tabular}

*) Huruf di belakang angka rata-rata yang berbeda menunjukkan perbedaan signifikan berdasarkan uji statistik dengan $\alpha=0,05$ (dalam satu baris yang sama)

Dari hasil perbandingan, didapatkan pengolahan terbaik yaitu bawang hitam berdasarkan nilai tertinggi pada aktivitas antioksidan, total senyawa fenolik, dan kadar vitamin $C$ yang dimiliki. Dapat terlihat adanya kesamaan tren antara kadar senyawa fenolik, kadar vitamin C, dan aktivitas antioksidan dalam sampel. Hal ini dapat dilihat dari tingginya nilai senyawa fenolik, vitamin C, dan aktivitas antioksidan pada bawang hitam yang berbeda secara 
nyata dengan bawang putih dan pickled garlic yang memiliki nilai paling rendah di antara ketiganya (Tabel 20). Adanya kesamaan tren tersebut dapat disebabkan karena komponen fenolik memiliki aktivitas penghambatan terhadap senyawa-senyawa radikal bebas (Dewi et al., 2009). Perbedaan komponen dan struktur fenolik dalam sampel dapat menyebabkan aktivitas antioksidan yang berbeda karena efek sinergis maupun antagonis juga dapat berbeda antara satu dengan yang lainnya (Niciforovic et al., 2010). Selain itu, vitamin C sendiri juga dapat berperan sebagai senyawa antioksidan dalam tubuh yang kuat dan pengikat radikal bebas, sehingga mampu menetralkan radikal bebas di seluruh tubuh (Kim, 2002). Adanya pembuatan bawang hitam menyebabkan kandungan allisin akan menurun dan sebaliknya diikuti dengan meningkatnya konsentrasi senyawa-senyawa baru. Senyawa yang dominan terkandung yaitu S-alil sistein (SAC) dan S-allilmerkaptosistein (SAMC) (Banerjee dan Maulik, 2002) yang juga merupakan antioksidan dalam umbi bawang putih. SAC dan SAMC mampu menghambat oksidasi yang disebabkan senyawa chemiluminescense dan mencegah pembentukan senyawa asam tiobarbiturat reaktif dalam hati. Kedua senyawa tersebut juga menghambat aktivitas radikal bebas DPPH (Imai et al., 1994).

Kadar protein tertinggi dimiliki oleh bawang hitam $(7,61 \%)$, kemudian kontrol $(3,1 \%)$, dan yang paling kecil dimiliki oleh pickled garlic $(1,45 \%)$ dengan perbedaan yang signifikan. Dari hasil tersebut dapat terlihat bahwa terjadi peningkatan kadar protein pada proses pengolahan bawang hitam, sedangkan pada proses pengolahan pickled garlic terjadi penurunan kadar protein (Tabel 20). Meningkatnya kadar protein atau $\mathrm{N}$ pada bawang hitam dapat terjadi karena peningkatan senyawa lainnya yang mengandung senyawa $\mathrm{N}$, seperti SAC.

Dari hasil penelitian, diketahui bahwa baik bawang putih, bawang hitam, maupun pickled garlic dapat menghambat pertumbuhan ketiga bakteri uji, baik pada Escherichia coli, Staphylococcus aureus, maupun Salmonella typhi (Tabel 20). Namun daya hambat yang dihasilkan tidak memiliki perbedaan yang nyata terhadap beberapa perlakuan yang diberikan pada bawang hitam maupun pickled garlic. Apabila dibandingkan dengan kontrol positif ampicilin dapat dilihat adanya perbedaan yang signifikan dengan daya hambat sampel uji namun tidak terlalu berbeda jauh, sedangkan dengan kontrol positif chloramphenicol terdapat perbedaan yang signifikan dan sampel uji memiliki aktivitas antimikroba yang jauh lebih rendah.

Salah satu senyawa fitokimia dalam bawang putih, yaitu allisin, merupakan senyawa aktif dalam bawang yang bersifat tidak stabil namun efektif dalam membunuh mikroba, seperti mikroorganisme penyebab infeksi. Allisin mempunyai daya antibakteri, daya aktivitas antifungi dan daya aktivitas antiparasit (Salama et al., 2014). Kandungan alliin bawang putih yang diremas akan segera teroksidasi menjadi allisin dan selanjutnya menjadi deoksi-alliin, DADS, dan DATS, suatu senyawa yang mempunyai aktivitas anti bakteri paling kuat (Yin et al., 2002). Aktivitas antimikroba sampel yang didapatkan cukup rendah dapat dipengaruhi oleh berbagai hal, salah satunya jenis pelarut yang digunakan. Pelarut yang berbeda dapat memberikan perbedaan kelarutan pada senyawa fitokimia, tergantung pada polaritas pelarut tersebut (Doughari, 2006).

Penurunan jumlah mikroba viable dapat terjadi karena pertumbuhan mikroorganisme dipengaruhi oleh banyak hal. Pertumbuhan mikroorganisme dapat tergantung dari ketersediaan air dalam bahan pangan. Bahan-bahan yang terlarut di dalam air akan digunakan oleh mikroorganisme untuk membentuk bahan sel dan memperoleh energi. Selain itu, suhu juga merupakan salah satu faktor lingkungan yang berpengaruh terhadap pertumbuhan mikroorganisme. Umumnya mikroorganisme pangan termasuk dalam kelompok mesofil yang mempunyai kisaran suhu pertumbuhan $20-45^{\circ} \mathrm{C}$.

\section{KESIMPULAN}

Suhu dan lama waktu pengovenan berpengaruh terhadap nilai fungsional bawang hitam dengan perlakuan terbaik pada suhu $80{ }^{\circ} \mathrm{C}$ dengan lama waktu pengovenan 40 hari. Kadar garam dan lama waktu penyimpanan berpengaruh terhadap nilai fungsional pickled 
garlic dengan perlakuan terbaik pada kadar garam $3 \%$ dengan lama waktu penyimpanan 40 hari. Pengolahan yang menghasilkan nilai fungsional tertinggi yaitu bawang hitam dengan aktivitas antioksidan $72,30 \%$, kadar senyawa fenolik total 1,09 mg GAE/g sampel, kadar vitamin C 0,348 \% b/b, dan kadar protein 7,61 \% N.

\section{PUSTAKA ACUAN}

Amagase, H. (2006). 'Significance of Garlic and Its Constituents in Cancer and Cardiovascular Disease: Clarifying the Real Bioactive Constituents of Garlic'. Journal of Nutrition, vol 136: 716S-725S.

Bae, S. E., et al. (2012). 'A Comparative Study of The Different Analytical Methods for Analysis of S-allyl cysteine in Black Garlic by HPLC'. LWT - Food Science and Technology, 46, 532-535.

Bae, S. E., et al. (2014). 'Changes in S-allyl cysteine contents and physicochemical properties of black garlic during heat treatment'. Food Science and Technology 55: 397-402.

Banerjee, S. K. dan Maulik, S. K. (2002). 'Effect of Garlic on Cardiovascular Disorders: a review'. Nutrition Journal 1 (4): 1-14.

Borek, C. (2001). 'Antioxidant Health Effects of Aged Garlic Extract'. J. Nutr. 131, 1010S-1015S.

Brands, C.M.J., Wedzicha, B.L., dan Boekel, M.A.J.S. (2002). 'Quantification of Melanoidin Concentration in Sugar-Casein Systems'. J. Agric. Food Chem. 50: 1178-83.

Casado, Fransisco J., et al. (2004). 'Nutritional Composition of Commercial Pickled Garlic'. Eur Food Res Technol 219: 355-359.

Chang, H. S., et al. (2005). 'Modulatory Influence of Sodium 2-Propenyl Thiosulfate from Garlic on Cyclooxygenase Activity in Canine Platelets: Possible Mechanism for the Antiaggregatory Effect'. Prostaglandins, Leukotrienes Essent. Fatty Acids, 72, 351355.

Delaquis, P. \& Mazza, G. (1998). 'Functional Vegetable Products'. Functional Foods, Biochemical and Processing Aspects (edited by G. Mazza). Pp. 193-233. Lancaster: Technomic Publishing.

Gorinstein, S., et al. (2008). 'Comparison of The Main Bioactive Compounds and Antioxidant Activites in Garlic and White and Red Onions After Treatment Protocols'. J. Agric. Food Chem, 56, 4418-4426.

Imai, J., et al. (1994). 'Antioxidant and Radical Scavenging Effects of Aged Garlic Extract and its Constituents'. Planta Medica 60 (5): 417-420.

loannou, I., et al. (2012). 'Review of The Effects of Food Processing and Formulation on Flavonol and Anthocyanins Behavior'. J. Food Eng, 111, 208-217.

Javanmardi, J., C. Stushnoff, E. Locke, dan J. M. Vivianco. (2003). 'Antioxidant Activity and Total Phenolic Content of Iranian Ocimum Accessions'. Journal Food Chemistry Vol. 83.

Jones M.G., et al. (2007). 'The Biochemical and Physiological Genesis of Alliin in Garlic'. Medicinal and Aromatic Plant Science and Biotechnology 1(1), 21-24.

Kim D.O., et al. (2002). 'Vitamin C Equivalent Antioxidant Capacity (VCEAC) of Phenolic Phytochemicals'. Journal Agricultural and Food Chemistry, 50(13):3713-17.

Kim, J., Kang, O., dan Gweon, O. (2012). 'Changes in the Content of Fat- and Watersoluble Vitamins in Black Garlic at the Different Thermal Processing Steps'. Food Sci. Biotechnology, 22(1); 283-287.

Manley, D. (2011). Sugars and Syrups as Biscuit Ingredients. Manley's Technology of Biscuits, Crackers, and Cookies (Fourth Edition).

Manzocco, L., et al. (2000). 'Review of Non-enzymatic Browning and Antioxidant Capacity in Processed Foods'. Trends in Food Science and Technology, 11, 340346.

Montano, Alfredo, et al. (2004). 'Vitamin Content and Amino Acid Composition of Pickled Garlic Processed with and without Fermentation'. J. Agric. Food Chem. 52, 73247330. 
Niciforovic, N., et al. (2010). 'Antioxidant Activity of Selected Plant Species; Potential New Sources of Natural Antioxidants'. Food and Chemical Toxicology. 48: 31253130.

Rejano, L., et al. (1997). 'Chemical Characteristics and Storage Stability of Pickled Garlic Prepared Using Different Processes'. Journal of Food Science, Vol. 62, No. 6.

Rejano, L., et al. (2004). 'Thermal Kinetics of Pungency Loss in Relation to the Quality of Pickled Garlic'. International Journal of Food Science and Technology 39, 311317.

Salama, A. A., et al. (2014). 'Inhibitory Effect of Allicin on the Growth of Babesia and Theileria Equi Parasites'. Parasitology Research 113 (1): 275-83.

Sayin, F. K. dan Alkan, S. B. (2015). 'The Effect of Pickling on Total Phenolic Contents and Antioxidant Activity of 10 Vegetables'. Journal of Food and Health Science, 1(3): 135-141.

Wang, Danan. et al. (2010). 'Black Garlic (Allium sativum) Extracts Enhance the Immune System'. Medicinal and Aromatic Plant Science and Biotechnology, vol. 4 (1). Hal: 37.

Woo, K. S., et al. (2007). 'Characteristics and Antioxidative Activity of Volatile Compounds in Heated Garlic (Allium sativum)'. Food Science and Biotechnology, $16,822-827$.

Xu, G., Ye, X., Chen, J., dan Liu, D. (2007). 'Effect of Heat Treatment on The Phenolic Compounds and Antioxidant Capacity of Citrus Peel Extract'. J. Agric. Food Chem, 55, 330-335.

Yin, M. C., H. C. Chang, dan S. M. Tsao. (2002). 'Inhibitory Effects of Aqueous Garlic Extract, Garlic Oil, and Four Diallyl Suphides Againts Four Enteric Pathogens'. Journal of Food and Drug Analysis 10(2): 120-126. 